\title{
GAME THEORY'S WARTIME CONNECTIONS AND THE STUDY OF INDUSTRIAL CONFLICT
}

\author{
GERD KORMAN and MICHAEL KLAPPER
}

$I^{\prime}$ N 1964, when Richard E. Walton and Robert B. McKersie finished their landmark work, A Behavioral Theory of Labor Negotiations: An Analysis of a Social Interaction System, game theory, an important feature of their work, had been around for at least twenty years. ${ }^{1}$ It had surfaced in the midst of World War II, and during the Cold War it had become a significant analytical tool not only for military analysts but also for opponents of war, who tried to develop general theories or systems that would explain conflict scientifically. Those students of game theory had helped to make it increasingly attractive to scholars in the field of labor relations who wanted to improve their understanding of industrial conflict.

This study traces the changing reactions to game theory of scholars interested in the study of industrial conflict, from the inception of the theory in the early 1940 s to its acceptance by many in the 1960s. The authors recapitulate the views of proponents and critics of the theory and emphasize the effect of World War II and the Cold War on that debate. They also describe the role of individuals such as Kenneth Boulding and Thomas Schelling and of institutions such as the RAND Corporation and the Ford Foundation's Center for Advanced Study in the Behavioral Sciences.

Gerd Korman is Associate Professor at the New York State School of Industrial and Labor Relations and Michael Klapper is a recent graduate of the New York University Law School._EDITOR

${ }^{1}$ Richard E. Walton and Robert B. McKersie, $A B e$ havioral Theory of Labor Negotiations: An Analysis of a Social Interaction System (New York: McGrawHill, 1965).
Game theory never did become the theory of choice of those students of industrial conflict weaned on institutional economics, but its wartime connections with students of war and peace are worthy of exploration. It was one of a number of quantitative analyses associated with the emerging breed of behavioral scientists and general systems analysts, true believers who had arrived on the scene when a strange environment enveloped the republic. It was a period of Manichean years. Gods of war ruled public passions. Americans considered themselves locked in a fatal struggle with the forces of evil in Germany, Japan, and then in Soviet Russia. All but a few citizens endorsed the extraordinary centralization of authority by the federal executive. On a scale never reached before, government officials and their experts used theories and quantitative techniques to calculate-and, Jacques Ellul would insist, to think-in an artificial statistical atmosphere. ${ }^{2}$ The focus on game theory and its wartime connections may therefore offer useful insights to the place of World War II and the Cold War in the development of analytical theories and methods that became important to a growing number of outstanding students in the field of industrial and labor relations.

${ }^{2}$ Jacques Ellul, The Technological Society (New York: Knopf, 1964), p. 163. For a good introduction to American society during World War II and the Cold War, see William E. Leuchtenburg, et al., The Unfinished Century (Boston: Little, Brown, 1973), pp. 526-69, 677-747. 


\section{College of Social Physicians}

Traditional students of domestic conflict, connected to the engines of Marshall or Commons, had over many years fashioned an approach intended to stabilize laborcapital conflict for the sake of gradual, moderate reform. Ever since 1871, when radical rhetoric and the thousands killed in the fight over the Paris Commune made the specter of industrial class warfare a horrible reality, uncontrolled labor-capital conflict became the nightmare for city dwellers who saw America's future tied to industrialization instead of commerce or agriculture. In the United States, the violence of railroad strikes between 1874 and 1877 , the explosion of organized worker power in 1886, and Homestead, Coeur d'Alene, and Pullman a few years later evoked sufficient fear from elected officials and masters of factories, railroads, and mines to use troops, then and later, for reestablishing the proper public peace.

The nightmare also haunted social scientists for whom industrial events had particular interest. Their professional thinking intertwined with all sorts of concepts and facts of personal history and of the society in which they lived. They responded especially to ideas and innovations associated with entrepreneurial liberty, various forms of Darwinism, and reforms of the progressive movement, and to the rules and regulations of World War I. But among American political economists who wanted to contain conflict between workers and their employers, two Darwinians served as master teachers: Marshall in England, and Commons in the United States. The two eschewed mathematics and statistics in their published work; they wanted to be useful and to serve the public interest; they wanted to institutionalize an invisible college of social physicians eager to help a democratic society improve itself; and they knew that uncontrolled internal conflict of industrial capitalism stood in their way, that it beckoned employer tyranny, class warfare, authoritarian governments, or socialism. ${ }^{3}$

${ }^{3}$ Arthur C. Pigou, ed., Memorials of Alfred Marshall (London: Macmillan, 1925), pp. 23-24, 66-67, 427; Arthur C. Pigou, Alfred Marshall and Current
The master teachers and those who came under their influence criticized each other and were subject to diverse attacks from outside their circles. The radical critics of industrial capitalism did not usually distinguish between Manchester and Madison and accused all as defenders of the system. Reformers, including Commons, charged the classical school of Marshall with deductive rigidity, with a belief in disembodied economic forces, moving inexorably by their own rules and working principally on individuals, and with opposition to redistributing income and power in capitalist America. Devotees of entrepreneurial liberty accused Commons and his students of constituting threats to that same system because they supported a trade union movement built around the national union and industrial democracy, because they wanted state legislatures to pass protective labor legislation, and because they fought for national social insurance programs intended to prevent economic hardship. ${ }^{4}$

Commons's institutional economics was especially porous because of his arrogant presumptions about race and American nationalism as governing elements in behavior, but his collegial opponents usually focused upon his understanding of economics. For Commons the human will in action precluded economics from becoming one of the physical sciences. To him and his students clinical economists studied power relationships as they occurred among free individuals and voluntary groups participating in transactions that constituted all of economic activity. ${ }^{5}$ To theoretical and quantitatively oriented opponents, clinical economists were akin to humanists who

Thought (London: Macmillan, 1953), pp. 7, 10, 11; J. K. Whitakker, ed., The Early Economic Writings of Alfred Marshall, 1867-1890 (London: Royal Economic Society, 1975), pp. 341-77; H. J. Dyos and Michael Wolff, eds., The Victorian City (London: Routledge, 1973), pp. 27-28, and $88 \mathrm{ff}$. provides background for Marshall's urban world in England. For Commons, see Gerd Korman, "John R. Commons," Dictionary of American Biography, Supplementary Volume III, pp. 176-80.

${ }^{4}$ Korman, “John R. Commons,” pp. 176-80.

${ }^{5}$ John R. Commons, Institutional Economics: Its Place in Political Economy (New York: Macmillan, 1934), pp. 55 ff., 73, 88. 
stressed the particular, doted on qualitative uniqueness, relied on so-called anecdotal evidence, and considered beyond measurement and testing the complex webs of human behavior. ${ }^{6}$

\section{Game Theory's Arrival}

Between World Wars I and II, the search for means of stabilizing conflict continued under changed circumstances and with new concepts. Some social scientists insisted that the price at which quantities could be exchanged was indeterminate. They thought it would be impossible to apply the analytical tools of the economist to yield more than an approximation; they argued that power, impervious to economic analysis, played a decisive role over the course of negotiations. But others began to feel that a model could be constructed that would lead to a solution of the distribution problem; they thought power could be analyzed by economic theory.

In the 1930s, when ideological passions, mass production unions, and industrial conflict dotted the landscape, John Hicks, in England, and those of like mind in the United States, examined wage determination from the perspective of that decade. They assumed that both the power of an employer and that of the union government could be analyzed by applying economic theories to the ways each related to wages. By the eve of World War II they had succeeded in contracting the zone of indeterminancy but, as they themselves admitted, part of that zone remained open. ${ }^{7}$

Students of conflict also considered other competing theories. Some insisted the firm was an economic model for trade unions.

${ }_{6}^{6}$ Pigou, Marshall and Current Thought, pp. 10, 11; Pigou, Memorials of Marshall, pp. 23-24, 66-67. For a general discussion of these controversies, see Joseph Dorfman, The Economic Mind in American Civilization, 1865-1918, Vol. 3 [Reprint] (New York: A. M. Kelley, 1969), pp. 359-90, and Ben B. Seligram, Main Currents in Modern Economics (Glencoe, Ill.: Free Press, 1963), pp. 628-65.

7John R. Hicks, ed., The Theory of Wages (London: Macmillan, 1932), pp. ix, 140-46, 152-56; Martin S. Bronfenbrenner, "The Economics of Collective Bargaining," Quarterly Journal of Economics, Vol. 53, No. 4 (August 1939), pp. 535-61.
Others, who stressed the union as a political institution, were especially concerned about the place of political behavior in economic conflict and in the process of bureaucratization, subjects that remained important in postwar years. ${ }^{8}$ There were also social scientists, who were not economists, who studied bargaining. Involved with theories of psychology and behavior, they used statistics or mathematical theory in their studies. Some of them looked back to the critics of Hicks and to starting points different from those of Marshall or Commons. Frederick Zeuthen, an economist in Denmark, reached back to Augustine Cournot, a nineteenth century economist who had used mathematical theory. Offering a psychological model of the bargaining process, Zeuthen insisted that the economic, political, and psychological components of that process could be analyzed and expressed quantitatively. $\mathrm{He}$ justified his approach this way:

Deduction takes place according to the rules of logic and, since in all essentials economics is concerned with the nature of the connection between quantities, this science must to a great extent apply quantitative logic, i.e. mathematics. This does not require that formulae and figures are going to occupy very much space. Logical verbal reasoning about quantities (without intermingling of irrelevant words) is also included in mathematics. ${ }^{9}$

During the interwar years social scientists

${ }^{8}$ See, for example, Sumner Slichter, Economic Factors Affecting Industrial Relations Policy in the War Period (New York: Industrial Relations Counselors, 1939) and Union Policies and Industrial Management (Washington: Brookings Institute, 1941), pp. ix-xiv, 371; Arthur Ross, "The Trade Union as a Wage Fixing Institution," American Economic Review, Vol. 37, No. 4 (September 1947), pp. 571-87; and "The Dynamics of Wage Determination Under Collective Bargaining," American Economic Review, Vol. 37, No. 5 (December 1947), p. 882; John T. Dunlop, Wage Determination Under Trade Unions, 2d. ed. (New York: Macmillan, 1950), p. 27; and J. Douglas Brown, The Industrial Relations Section of Princeton University in World War II: A Personal Account (Princeton: IRS, 1976).

${ }^{9}$ Frederick Zeuthen, Problems of Monopoly and Economic Warfare [Reprint] (New York: A. M. Kelley, 1968), pp. 3, 25, 64, 65, 104-21. See also Frederick Zeuthen, Economic Theory and Method (Cambridge: Harvard University Press, 1955), pp. 6-10 (quotation from p. 17), and Gerard Shove's review of Hicks's The Theory of Wages (1932 edition) in Hicks, The Theory of Wages (1963), pp. 249-65. 
with Zeuthen's orientation had important intellectual company. It was a period when political ideologies of assimilation, socialism, fascism, and Communism strove to control and make predictable the behavior of masses of people by eliminating differences among individual and cultural groups for the sake of the will of the nation, the state, or the industrial working class. It was also a time when the implications of the work of Erwin Schroedinger, Albert Einstein, and Neils Bohr came to be felt outside their world of quantum mechanics and other aspects of theoretical physics. Statistics and mathematics had become of increasing importance to other scholars seeking to understand intersecting problems originating in economics and such other subjects as organismic biology, psychology, sociology, quality control, and management analysis. ${ }^{10}$

John von Neumann, the chemical engineer from Budapest, read his seminal paper on game theory to the Mathematics Society at Goettingen, Germany in 1928 and soon after wrote some of his papers on the logic design of computers, turning in part to biology and in part to physiologists Warren S. McCullock and Walter Pitts, who were trying to make a mathematical model of the human nervous system. In the meantime in Austria, Oskar Morgenstern sought to transcend the limitations of traditional economic analysis. With German National Socialists infesting his world of scholarship with supercharged political theology, he wrote an essay focusing attention upon the "methodological controversy and the discussion of the neutrality of economics as between different value judgments." Morgenstern also wanted "to reduce the level of abstraction of the theory of wages by the insertion of con-

\footnotetext{
${ }^{10}$ James D. Watson, The Double Helix (New York: Atheneum, 1968), pp. 13-14, 15, 22-23, 192; Richard B. Goldschmidt, "The Impact of Genetics Upon Science," G. W. Beadle, "Chemical Genetics," and Boris Ephrussi, "Remarks on Cell Heredity," all three in L. C. Dunn, ed., Genetics in the Twentieth Century (New York: Macmillan, 1951), pp. 22-23, 236, 237, 243-44; Gerald Holton, "The Roots of Complementarity," Daedalus, Vol. 99, No. 4 (Fall 1970), pp. 101555 and Robert Olby, "Francis Crick, DNA, and the Central Dogma,” Daedalus, Vol. 99, No. 4 (Fall 1970), pp. 938-87.
}

crete data." But keeping economics free from value judgments was not so important to him as was scholarly "independence." $\mathrm{He}$ wanted to eliminate all barriers of dogmatic presumption that affected the economist's explanation of cause and effect. ${ }^{11}$

At Princeton between 1939 and 1944, building on von Neumann's earlier paper, von Neumann and Morgenstern developed their original model for problem-solving situations. As quantum mechanics and organismic biology had done before, game theory assumed different "habits of behavior that cannot be changed simultaneously and that can usually be counted on to remain unchanged." 12 In their treatise, Theory of Games and Economic Behavior, the authors argued against social scientists such as Commons who objected to the creation of parallels between the physical sciences and their disciplines. They drew extensively from elementary notions of physics. Past failures in applying mathematics to conflict and tension in economics did not impress them. Economic questions had not been formulated clearly and were often stated in "such vague terms as to make mathematical treatment a priori appear hopeless." Obviously there was no point in using exact methods if there was no "clarity in the concepts and issues to which they are to be applied." They implied disagreement with Marshall when they insisted that mathematics involved more than translating verbal expressions into symbols. ${ }^{13}$

Von Neumann and Morgenstern's interwar gestation years had led them to an uncommon breed of camel, and in the midst of war, they tried to push its head into the tents of the economics profession. They en-

\footnotetext{
${ }^{11}$ Oskar Morgenstern, The Limits of Economics, translated by Vera Smith (London: W. Hodge, 1937), pp. 137, 153-55; Seligman, Main Currents, pp. 772-79, 789; Jeremy Bernstein, "When the Computer Procreates," New York Times Magazine, February 15, 1976, pp. 9, 34-38, Von Neumann's paper, "Zur Theorie der Gesellschaffspiele," was published in Mathe matische Annalen, Vol. 100 (1928), pp. 295-320.

${ }^{12}$ Ernest Nagel, The Structure of Science: Problems in the Logic of Scientific Exploration (New York: Harcourt, 1961), p. 473.

${ }^{13} \mathrm{John}$ von Neumann and Oskar Morgenstern, Theory of Games and Economic Behavior (Princeton: Princeton University Press, 1944), pp. i, 3, 4.
} 
countered opposition, partially because economists were forced at that point to decide if game theory revealed and filled a cultural gap in the empirical realm of economics. "Of course, mathematics was no stranger to economics," explained Ben B. Seligman some years later, "but, up to this point major reliance had been placed on the infinitesimal calculus.... Game theory ventured into a relatively new realm of mathematics ... it was a kind of mathematics seldom seen in economics with concepts drawn from theory, group theory, and mathematical logic."14 There were some public supporters-Jacob Marschak was one-but most economists involved with problems of conflict left the camel in splendid isolation. Martin Shubik thought most of his traditional colleagues left Theory of Games and Economic Behavior alone because they would not or could not read it. ${ }^{15}$ Some, however, gave it serious consideration before rejecting it or connecting it to earlier patterns of economic thought about conflict.

The book was rejected as inadequate on theoretical grounds or attacked because it made assumptions about economic behavior that critics insisted contradicted experience. Carl Kaysen, for example, attacked the applicability of the most basic tenets of game theory to economics. The relationship between the value of the game described by von Neumann and Morgenstern and the effects of relative "bargaining power" was never explicitly developed in the theory. Kaysen seemed to think that game theorists would profit from acquaintance with the multiplicity of bargaining forces that lead to a given solution, forces exemplified in the seemingly outdated analysis of the length of strikes in Hicks's Theory of Wages. In any event, Kaysen concluded, "this new method of analysis does not represent the revolution in economic theory which its authors (and Professor

\footnotetext{
${ }^{14}$ Seligman, Main Currents, p. 773.

${ }^{15}$ Jacob Marschak, “[Von] Neumann's and Morgenstern's New Approach to Static Economics," Journal of Political Economy, Vol. 54, No. 2 (April 1946), pp. 114-15; Martin Shubik, "Information, Theories of Competition, and the Theory of Games," Journal of Political Economy, Vol. 60, No. 2 (April 1952), p. 147; Martin Shubik, "The Role of Game Theory in Economics," Kyklos, Vol. 6, Fasc. 1 (1953-54), pp. 21-22.
}

Marschak) think it does." 16

In 1952 Seligman, a history-conscious economist, examined the von NeumannMorgenstern approach to game theory and found that many of its ideas seemed consistent with those of "non-mathematical economists" whose experience since the 1890 s came from the field of labor relations. Commons had been concerned with transactions as the starting point of economic action. He framed analysis in terms of the fixed sum of national income and the shifting composition of groups contending for it. Seligman found an obvious similarity in the game theorists' approach to coalition formation.

. . . game theory, with its emphasis on the elements of futurity and instability, calls attention to the urgent need to sustain in our system an equality of bargaining strength. If the scales shift away from such an equilibrium, the price that most of us would pay can very well be measured in political terms-in the language of game theory, in the loss of the right to be a recipient in the distribution of the winnings. ${ }^{17}$

Unable to make the dramatic impact upon economic theory they had envisioned, von Neumann and Morgenstern looked elsewhere. One of their students explained: "The initial reaction of the economists to this work was one of great reserve." Military scientists, on the other hand, "were quick to sense ... [game theory] possibilities in their field." 18 Von Neumann and Morgenstern pushed its development in the early months of the Cold War, especially in a new project called RAND, which was helping to attract civilians eager to attack the complex problems of international relations in the postwar world.

${ }^{16}$ Carl Kaysen, "A Revolution in Economic Theory?" Review of Economic Studies, Vol. 14, No. 1 (1946-47), pp. 12-15 (quotation from pp. 14-15). See also David Champernowne, "A Note on J. V. Neumann's Article on 'A Model of Economic Equilibrium'," Review of Economic Studies, Vol. 13, No. 1 (1945-46), pp. 15, 17-18.

${ }^{17}$ Ben B. Seligman, "Games Theory and Collective Bargaining," Labor and Nation, Vol. 8, No. 1 (January-March 1952), pp. 48-52.

${ }^{18} \mathrm{John}$ D. Williams, The Compleat Strategyst:Being a Primer in the Theory of Games and Strategy (New York: McGraw, 1954), pp. vii, 215, 216-17. For a historical survey of RAND, see Bruce L. R. Smith, The Rand Corporation (Cambridge: Harvard University Press, 1966), pp. 60-65. 


\section{The RAND-Ford Connection}

Game theory's entry to RAND became the critical link in the wartime connection between students of conflict worried about war and peace and students of industrial and labor relations. World War II had prepared the way for the event. The emphasis for comprehensive planning during the war had found interested parties outside labor economics and military circles. The Office of Scientific Research and Development (OSRD), a federal wartime agency established to bring clinical scholarship to military and industrial problems, had brought together civilians and soldiers under the leadership of M.I.T.'s Vannevar Bush and Karl T. Compton and Harvard's James P. Conant. The three had been close associates and all had reputations as successful organizers of American science. Possessed by a sense of urgency, these men usually turned to 20 of the most successful universities and corporations and there, on contract, recruited all sorts of scholars on behalf of the army and navy. ${ }^{19}$ Among its many activities, the agency organized experts for helping administrators make daily decisions and policy planners make judgments about the more distant future. Besides recruiting von Neumann and others to the teams that built the first atomic bombs, OSRD also organized teams of mathematicians, statisticians, psychologists, sociologists, and economists. Increasingly, these civilians became part of work groups that included military men who wanted decisive answers about the different effects of bombing, the use of fighter covers on long-distance air raids, ideal convoys, or the behavior of soldiers and civilians in the lands of the enemy. Civilians were also needed for a subject Walter E. Stewart had studied for some years at Western Electric: Statistical Quality Control-a process that was expected to speed up quality control in the manufacture of munitions. Captain G. L. Schuyler of the Bureau of Ordinance in the navy turned to the Statistical Research Group of Columbia University, which then included Milton Friedman and

\footnotetext{
${ }^{19} \mathrm{John}$ M. Blum, $V$ Was for Victory: Politics and American Culture During World War II (New York: Harcourt, 1976), pp. 144-45.
}

Allen Wallis, to study the problem of sequential analysis under the general direction of the Applied Mathematics Panel of the National Defense Research Committee. ${ }^{20}$

At war's end, some of the work that had come under the jurisdiction of the Office of Research and Development had been continued at Douglas Aircraft as Project RAND, as a result of a special agreement between General Hap Arnold of the U.S. Air Force and the management of the company. The bulk of RAND's work was directed toward mathematics, physics, and engineering, but as early as the winter of 1947 the clinical social sciences also began to take root. Scholars in universities and corporations turned to RAND as part of a natural habitat in which to continue work started during the war. But there were other reasons for RAND's attractiveness. General Dwight D. Eisenhower, then Chief of Staff, expressed shared concerns as well as anybody. In 1946, for the General and Special Staff Divisions of the Army, he issued a memorandum calling for a national policy that would continue the alliances fashioned during the war between soldiers and scholars: the "future security of the nation demands that all those civilian resources which by conversion or reduction constitute our main support in time of emergency be associated with the activities of the Army in time of peace.",21

Questions of war and peace remained critical to these sorts of soldiers and civilians. As the Paris Commune had haunted an earlier generation, the specter of Hiroshima or Communist domination haunted these men returning to private life and others especially attracted to game theory or any other theory or tool seemingly capable of solving postwar problems. Project RAND at Douglas was one of the few places in the United States able to take advantage of their

\footnotetext{
${ }^{20}$ Abraham Wald, Sequential Analysis (New York: Wiley, 1947), p. 2; S. Ulam, et al., "John von Neumann, 1903-1957," in Donald Fleming and Bernard Baylin, eds., The Intellectual Migration (Cambridge: Harvard University Press, 1969), pp. 235-48. On Stewart's pioneering work, see Daniel J. Boorstin, The Democratic Experience (New York: Vintage, 1974), pp. 195-200, 635 .

${ }^{21}$ Smith, Rand, pp. 32n, 39, 41.
} 
special interests, and so the Ford Foundation assisted RAND in becoming independent. Ford trustees were receptive to a RAND appeal to transform the project at Douglas into a nonprofit enterprise. J. Rowan Gaither-a San Francisco lawyer well connected to his city's financial circles, to RAND's management, and to the Ford Foundation's Board of Trustees-helped to bring the two organizations together. From banks in San Francisco Gaither received offers to put up $\$ 600,000$ for the new RAND enterprise if the RAND people could produce $\$ 400,000$ of their own working capital; from Ford he obtained a $\$ 100,000$ loan without interest and a guarantee for the other $\$ 300,000$ needed to obtain the remainder of the working capital. Gaither himself became the influential head of RAND's Board of Trustees. RAND began its independent corporate life in relative secrecy with a contract from the air force. ${ }^{22}$

The Ford Foundation's new creature had a broad and amorphous mission-to study "preferred techniques and instrumentalities of intercontinental warfare"; within that framework it generated a wealth of materials including pioneering "payoffs" for systems analysis, the "Monte Carlo" method, war gaming and simulation, and formal game theory. Between 1948 and 1962, the period of Gaither's chairmanship, RAND circulated approximately 300 papers, reports, and research memoranda on game theory and its applications to logistics and national defense, both in limited war and nuclear confrontation. As early as 1953, von Neumann and Morgenstern acknowledged their debt to the RAND Corporation for its continuing efforts to build upon the theory that the authors had introduced. Indeed, Morgenstern developed working papers for the RAND Corporation on the mathematical theory of strategy and the logistics of supply, which formed the basis for his 1959 publication, The Question of National Defense. Shubik developed papers

\footnotetext{
${ }^{22}$ Dwight Macdonald, The Ford Foundation: The Men and the Millions (New York: Reynal, 1956), pp. 8-11; Smith, Rand, pp. 39-111; "Air Force Forms 'RAND Corporation' . . ., New York Times, November 5, 1948, Late City Edition, p. 15; S. Ulam, "John von Neumann," pp. 235-48.
}

on a comparative study of treatments of duopoly; Marschak pursued the optional choice of weapons; and von Neumann continued refinements on the theory of games. ${ }^{23}$

Under Gaither's leadership the Ford Foundation also tried to channel thought and research into other problems of conflict resulting from the Cold War. While chairman of RAND's Board of Trustees, he served in 1948 and 1949 as the chairman of the committee that studied new opportunities for the Ford Foundation. ${ }^{24}$ His important report to the trustees reflected the Cold War world with which RAND was preoccupied. It looked for new ways of studying and managing or stabilizing conflict on behalf of American interests and values. It revealed how the Cold War affected the Ford Foundation's thinking about pure and applied social science research as it related to conflict and its causes. In other words, the report presented the framework within which occurred game theory's wartime connection with the study of labor relations. It deserves closer scrutiny.

The report proclaimed traditional American values in the context of the Cold War. Each individual had an inherent worth. Human interdependence could be exploited by men or states. Faith in the future and immediate material benefits served people as criteria when choosing between free societies and totalitarian ones. The danger from abroad was real, the stakes high: "the tide of communism mounts in Asia and Europe, the position of the United States is crucial. ... This country must be prepared militarily for any future eventuality. . . ." At home threats to the democratic tradition were also serious. Suspicion, hysteria, and expediency

\footnotetext{
${ }^{23}$ Von Neumann and Morgenstern, Theory of Games (1953), pp. vii-viii; Williams, The Compleat Strategyst, pp. 215, 216-17; Rand Corporation, Index to Selected Publications of the Rand Corporation I: 19461962 (Santa Monica: Rand, 1962), pp. 5141-47; Martin Shubik (with John Mash and J. P. Mayberry), "A Comparison of Treatments of a Duopoly Situation," (with K. H. Arrow and T. E. Harris), "Optimal Inventory Policy," and (with M. R. Mickey, Jr.), "Notes on the Optional Choice of Weapons," all in Rand, Index, pp. P-222, P-189, P-470; Smith, Rand, p. 157. See also Herman Kahn and Anthony Wiener, The Year 2000 (New York: Macmillan, 1967), pp. 35-36.

${ }^{24}$ Macdonald, Ford, p. 11.
} 
abounded as citizens feared treason and jeopardized freedom. The country's conduct must not be "based solely upon fear of communism, upon reactions to totalitarian tactics, or upon the immediate exigencies of avoiding war. ... We may grow like the thing we fight." 25

The report identified unrest and social instability as the basic cause of war and appreciated the centrality of a strong and stable American economy in rehabilitating "free countries of the world" and in withstanding "totalitarian pressures" against them. ${ }^{26}$ But having so diagnosed the interrelatedness of domestic and foreign affairs, Gaither et al. insisted that the social sciences had neither the theories nor methods necessary for coping with the complex problems of the Cold War. In economics theoretical thinking needed support for developing techniques such as sampling and intellectual approaches that recognized that "man's economic behavior is only a part of his total behavior." Man's economic choices were recognized as constituting simply one part of the entire range of human choices and decisions subject "as much to nonlogical factors as any other human conduct." Similar support was needed for newer disciplines such as psychology, sociology, and anthropology, but all these disciplines were simply incapable of providing the scientifically reliable and verifiable knowledge necessary for identifying the causes of conflict: "The study of human and social behavior does not have a long and established tradition of scientific research. Much of the work in these fields has been polemical, speculative, and prescientific." 27

Collective bargaining and industrial conflict at home and abroad needed comparable attention, for a scientific understanding of such subjects was a prerequisite for maintaining strong free economies against totalitarianism. The absence of industrial peace resulted in lost income, inconvenience, and social friction. "Substantial progress in solving this problem requires a more

${ }^{25} \mathrm{H}$. Rowan Gaither, Jr., et al., Report of the Study for the Ford Foundation on Policy and Program (Detroit: Ford Foundation, 1949), pp. 17, 19-22, 26, 28-29.

${ }^{26}$ Ibid., pp. 26, 71.

${ }^{27}$ Ibid., pp. 72, 74, 92-96; Macdonald, Ford, pp. 80-81. complete knowledge of what constitutes effective organization and administration in business firms and unions, and a more complete understanding of human behavior." The report pinpointed two targets especially. Contracts between a powerful union and a large firm presented important concerns because they involved technological change and other important public issues such as mobility of workers and regularity of employment. The other target was the trade union itself: it represented and governed workers but did not always maintain responsible governments devoted to rules of justice for its members or the general public. To Gaither et al. it was obvious that here as elsewhere in the social sciences, increased knowledge of human behavior would be of great value in solving such economic problems as those encountered in labor-management relations. ${ }^{28}$

Through different forms of financial support Ford translated into action the emphasis of the report. One form, in applied research, went to Clark Kerr, John Dunlop, Frederick Harbison, and Charles Myers for systematic comparative studies of international systems of industrial and labor relations. ${ }^{29}$ Other forms allowed the foundation to bring together those scholars working in the areas of social science research the Gaither report had identified as important. One of these groups was associated with the University of Michigan and was to have a special place in the study of conflict and labor relations.

\footnotetext{
${ }^{28}$ Gaither, Report, p. 35

${ }^{29}$ The relation of their study to the Cold War features of the Gaither report can be appreciated by comparing prefaces of the 1960 and 1964 editions of Industrialism and Industrial Man. In 1960, on page 4, they reported on their justification when they first applied for funds. It includes this passage which they excised from the 1964 preface: ". . . we pointed out that effective operation [abroad] was particularly important to Americans, since the world is torn between two great approaches to the organization of industrial society." Clark Kerr, John T. Dunlop, Frederick Harbison, and Charles Myers, Industrialism and Industrial Man (Cambridge: Harvard University Press, 1960), pp. 4-5 and (New York: Oxford University Press, 1964), pp. 5-6. See also James L. Cochrane, "Industrialism and Industrial Man in Retrospect," in Industrial Relations Research Association, Proceedings of the Twenty-Ninth Annual Winter Meeting, September 16-18, 1976, pp. 274-87.
} 


\section{The Michigan Connection}

Between 1949 and 1954, in the midst of the Cold War and at the height of Senator Joseph McCarthy's anti-Communist and anti-Russian scare campaigns, a number of scholars sharing pacifist attitudes found each other. They met at the University of Michigan and in Palo Alto, the new home of the Ford Foundation's Center for Advanced Study in the Behavioral Sciences. All social and biological scientists, they, too, looked for new ways of thinking to prevent war.

In Ann Arbor, Viennese-born Herbert Kelman, a young social psychologist, and Kenneth E. Boulding, a Quaker pacifist and economist, attracted likeminded colleagues to the subject of conflict resolution. Kelman sparked successful efforts to publish a new bulletin for exchanging research information and for holding workshops on the subject of their enthusiasm. "We were amateurs responding to moral issues of the day in seeking to apply our social scientific tools to problems of war and peace," recalled Kelman years later. ${ }^{30}$

By the time Boulding joined the Michigan faculty he had already started moving toward "general systems." 31 By his own account his intellectual direction had been most affected by the works of three authors whose subjects "all lie outside the regular academic disciplines."

They are first, the pioneering work of Chester Barnard, The Functions of the Executive [1938]. From this comes the central idea of the executive or "central agent" of any organization as a receiver of information and an issuer of orders. The second work is Norbert Wiener's Cybernetics [1948]. In this the notion of the executive as the center of a control mechanism whereby through the feedback of information divergences from ideal values are corrected, fills out and supplements the theory of organization of Barnard. The third book, [Claude E.] Shannon and [Warren] Weaver's The Mathematical Theory of Communication [1949], is the bible of information theory. The development of a mathematical concept of information parallels in its importance the development of the concepts of mass and energy in physics. It has opened up the possibility of a new and more quantitative approach

\footnotetext{
${ }^{30}$ Interview with Herbert Kelman, May 18, 1976.

${ }^{31}$ Letter from Kenneth E. Boulding to Gerd Korman, August 27, 1975.
}

to the whole problem of organization..$^{32}$

At Michigan, Boulding combined this interest with his devotion to pacifism. He organized a seminar on "The Integration of the Social Sciences." This, he recalled, "turned out to be a seminar on any thing that wanted to be integrated, and eventually led into general systems." ${ }^{33}$ It had also led to contacts with Ludwig Bertalanffy who, on the basis of his studies in biology, as early as 1945 had revealed his movement toward an abstract field of study called "general systems theory." 34

In Palo Alto in 1954 (the year of Robert Oppenheimer's ouster from the Atomic Energy Commission, an agency on which von Neumann also served) Kelman, Boulding, and Bertalanffy came together with likeminded scholars-Clyde Kluckholn, Harold Laswell and Paul Lazarsfeld-for a year of study. They had been selected by screening groups under the aegis of Chicago's Bernard Berelson, a quantifier of behavior and head of the foundation's Behavioral Science Division. Also selected was Anatole Rapoport, a mathematical biologist with intellectual interests and moral values that easily attracted him to the Michiganders. Together these scholars looked for ways to develop general systems to help them understand and analyze their subjects of interest, and to find technical tools (such as game theory) for studying situations of conflict.

It was in Palo Alto that Rapoport, Boulding, and Bertalanffy decided to launch their society for general systems; a few years later, under the editorship of Bertalanffy and Rapoport, the society began to publish its annual volumes. Rapoport also became involved with the ideas behind the Michigan

\footnotetext{
${ }^{32}$ Kenneth E. Boulding, The Image (Ann Arbor: University of Michigan Press, 1956), p. 153.

${ }^{33}$ Boulding to Korman.

${ }^{34}$ Bertalanffy's work is described in Nagel, Structure of Science, pp. 432-33; Paul A. Weiss, "The Living System: Determinism Stratified," in Arthur Koestler and J. R. Smythies, eds., The Alpbach Symposium 1968: Beyond Reductionism, New Perspectives in the Life Sciences (New York: Macmillan, 1969), pp. 14, 17; T. M. Sonneborn, "The Role of the Genes in Cytoplasmic Inheritance," in Dunn, Genetics in the Twentieth Century, pp. 308-11.
} 
bulletin. He was especially interested in the psychological aspects of game theory, but more importantly he, too, held strong moral judgments against war. Kelman, Boulding, and Rapoport began serious discussions for establishing a major journal that would subsume the bulletin Kelman had started.

Shortly after Palo Alto, Rapoport went to Michigan; there, these three plus some graduate students, tried to combine models of mathematics and systems analysis in the study of conflict. ${ }^{35}$ They were convinced that the "behavior and interactions of nations are not an isolated self-contained area of empirical material but part of a much wider field of behavior and interaction." According to Boulding, they began with the premise that "in order to develop a theoretical system adequate to deal with the problems of war and peace, it is necessary to cast the net wider and to study conflict as a general social process of which war was a special case." 36 In 1957 the Michigan group established the Journal of Conflict Resolution. Through it and the Center for Research of Conflict Resolution, founded two years later, the Michigan scholars-Boulding called them "peacenicks" - tried to translate their moral concerns into systematic studies of conflict. To them this study approach differed from the operational one they thought was in vogue at RAND. They acquired important help from Steven Richardson, the son of Lewis F. Richardson-an English physicist and Quaker pacifistwho made available his father's scientific papers and unpublished manuscripts on war and peace. ${ }^{37}$

Initially in the drive for developing an integrated theory of conflict, the group was especially interested in labor relations. Boulding's interest in labor economics reached back to 1943 when Iowa State College at Ames gave him a year off to study the subject. He "read very extensively in the

\footnotetext{
${ }^{35}$ Boulding, Image, p. 162; Boulding to Korman; interview with Kelman; Macdonald, Ford, pp. 80-83.

${ }^{36}$ Editorial in Journal of Conflict Resolution, Vol. 1, No. 1 (March 1957), pp. 1-2; Boulding to Korman.

${ }^{37}$ Boulding to Korman; interview with Kelman. The Journal of Conflict Resolution, Vol. 1, No. 3 was devoted to Lewis F. Richardson; Rapoport served as guest editor of the volume.
}

field ... [and] visited the offices of 85 international unions." $\mathrm{He}$ examined the proceedings of all the conventions that he could find, and recalled "visiting among the locals in Iowa." He never wrote much about the subject but his experience affected him profoundly: "I always say that going to Ames to become a labor economist was what really ruined me as a pure economist and led eventually to general systems." 38 The first volume of the Journal of Conflict Resolution reflected the group's interest in industrial relations. In addition to an article on the peaceful settlement of industrial and intergroup disputes by Ann Douglas, a young student of industrial and labor relations, the journal then and later published reviews of books discussing collective bargaining, and editorially explained the connection between labor disputes and international relations. More importantly from the perspective of the emerging general systems approach, the Michigan group recognized the relationship between problems of conflict resolution, institutional economics in general, and industrial relations in particular. The first volume of the journal explained:

Many of the patterns and processes which characterize conflict in one area also characterize it in others. Negotiation and mediation go on in labor disputes as well as in international relations. Price wars and domestic quarrels have much the pattern of an arms race. Frustration breeds aggression both in the individual and in the state. The jurisdictional problems of labor unions and the territorial disputes of states are not dissimilar. It is not too much to claim that out of the contributions of many fields, a general theory of conflict is emerging. ${ }^{39}$

That interest, however, was short-lived. When Ms. Douglas "dropped out of sight," remembered Boulding, "there was nobody

\footnotetext{
${ }^{38}$ Boulding to Korman.

${ }^{39}$ Editorial in Journal of Conflict Resolution, Vol. 1, No. 1 (March 1957), p. 2; Ann Douglas, "The Peaceful Settlement of Industrial and Intergroup Disputes," Journal of Conflict Resolution, Vol. 1, No. 1, pp. 6981; Jesse Berrard, (an article entitled) "Paging Arnold Toynbee! -A Review of [several volumes], "Journal of Conflict Resolution, Vol. 12, No. 1 (March 1968), pp. 113-19. Occasionally articles on labor-management conflict would also appear: see, for example, Vol. 3, No. 2 (June 1959), pp. 146-52; Vol. 9, No. 1 (March 1965), pp. 118-26; Vol. 11, No. 4(December 1967), pp. 398-413.
} 
else to pursue the interest." Boulding, the Quaker pacifist, did not provide a link to industrial and labor relations because his primary interest had shifted to applying mathematical systems to the peaceful solution of international conflicts. ${ }^{40}$

\section{Wider Circles}

Thus, von Neumann, Morgenstern, Boulding, Rapoport, Bertalanffy, RAND, and the people around the Journal of Conflict Resolution had not directly affected bargaining theory in the world of industrial and labor relations. Game and general systems theory had continued to attract military planners, biologists, biochemists, and international conflict specialists, however, and through operations research and systems analysis corporation managements also continued to play an important part in uses of these tools and concepts. ${ }^{41}$ In general, though, lines of thought about bargaining in the domain of industrial and labor relations remained traditional.

To be sure, there were exceptions. Dunlop was another economist who, like Boulding, sensed an affinity between general systems theory and the actual behavior of people in unions, managements, and governments. He had been especially persuaded by Talcott Parsons, an influential sociologist and colleague at Harvard whose originality had also been touched by Marshall, the institutionalists, Edwin Schroedinger, and other theoretical thinkers in biology, Harvard's physiologist L. H. Henderson and his inter-

\footnotetext{
${ }^{40}$ Boulding to Korman.

${ }^{41}$ D. G. Brennan, "Strategy and Conscience," and Anatole Rapoport, "The Sources of Anguish," both in Bulletin of the Atomic Scientists, Vol. 21, No. 10 (December 1965), pp. 25-30, 31-36; Sir Solly Zuckerman, "Judgment and Control in Modern Warfare," Foreign Affairs, Vol. 40, No. 2 (January 1962), pp. 196212; Michael Macoby, "Social Psychology of Deterrence," Bulletin of the Atomic Scientists, Vol. 17, No. 7 (September 1961), pp. 278-81; Arthur Waskow, "American Military Doctrine," in Seymour Melman, ed., Disarmament (Boston: American Academy of Arts and Sciences, 1962), pp. 193-211, (quotation from p. 207). See also Bruce Wallace, "On Decision Making," "Brinksmanship: The Limits of Game Theory," and "Reaching a Simple Decision," all in Bruce Wallace, ed., Essays in Social Biology, Vol. 1: People, Their Needs, Environment, Ecology (Englewood Cliffs, N.J.: Prentice-Hall, 1972), pp. 89-91, 157-58, 250-56.
}

est in the Italian economics and sociologist Vilfredo Pareto. ${ }^{42}$ As part of the Ford-funded study in comparative international industrial and labor relations, Dunlop declared that "an economic system can be regarded as a subsystem of the more general total system," and stated that an "industrial relations system is not a subsidiary part of an economic system but is rather a separate and distinctive subsystem of the society, on the same plane as the economic system." He defined the structure of an industrial relations system in terms of its political, social, and economic content, the establishment of rules, the formation of an ideology, and the behavior of its actors. ${ }^{43}$

When Dunlop published his Industrial Relations Systems in 1958, the Manichean years were beginning to come to an end. As Eisenhower had been a spokesman on behalf of a military-industrial-academic complex so, too, was he to become symbolic, as retiring president, of the changes beginning to occur. In his famous Farewell Address he echoed sentiments expressed eleven years earlier in the Gaither report, even as it had urged the Ford Foundation to contribute to the complex. Eisenhower pointed to an important development in the republic since the end of World War II. "This conjunction of an immense military establishment and a large arms industry is new in the American experience." Eisenhower said this was in large part the result of "the technological revolution during recent decades. ... [in which] research has become central. ... the solitary inventor ... has been overshadowed by task forces ... in laboratories and testing fields. ... the free university, historically the fountainhead of free ideas and scientific discovery, has experienced a revolution in the conduct of research .... . [and] a Government contract has become virtually a substitute for intellectual curiosity." In the Manichean years the change had gone so far as to create danger: "public

\footnotetext{
${ }^{42}$ For Parsons, see his "On Building Social System Theory: A Personal History," Daedalus, Vol. 99, No. 4 (Fall 1970), pp. 826-81; John T. Dunlop, Industrial Relations System (New York: Holt-Dryden, 1958), pp. 4-5.

${ }^{43}$ Dunlop, Industrial Relations System, pp. 4-5, 7-18.
} 
policy could itself become the captive of a scientific-technological elite." He called for a national alert warning against the Cold War's impact upon the life of "every city, every statehouse, every office of the Federal Government." 44 In other words, he had come to fear the special set of circumstances that had made behavioral science and general systems theory appear so potent for understanding and managing conflict.

In these same years game theory out of RAND also underwent changes, which helped make it possible for some within the tent of industrial and labor relations to admit a variant breed of the von NeumannMorgenstern camel. Scholars in RAND, and the Michigan group, each in their own way contributed to the cleansing process making game theory more useful than it had been when von Neumann and Morgenstern first introduced it. Formal criticism of game theory and experience with it at RAND and Michigan revealed all sorts of problems. RAND strategists used it less than before: instead, "war gaming, a dynamic simulation process," became a common technique. Their Cold War concepts about Russian and American designs also became less Manichean. They recognized the "central truth ... that many of the goals of the Soviet Union conflict with those of the United States," said D. G. Brennan, expressing a view shared by Henry Kissinger and such other important strategists as Thomas Schelling and Herman Kahn. But by this time it did not "appear that any of these conflicting goals are such as both of us would be prepared to support by going to war." 45

Behaviorists also helped to ease the camel of game theory into the tent of industrial and labor relations. Some scholars representing disciplines in the Industrial Relations Research Association had started to grapple with bargaining problems. They tended to associate themselves with the subject matter in Human Behavior, the encyclopedic guide to behavioral science of which Bernard

${ }^{44}$ The Farewell Address of January 18, 1961 may be found in James L. Clayton, ed., The Economic Impact of the Cold War (New York: Harcourt, Brace and World, 1970), pp. 24l-44.

${ }^{45}$ Brennan and Rapoport, Bulletin of the Atomic Scientists, pp. 27-28.
Berelson was senior compiler. Previously, as the director of the Ford Foundation's Behavioral Science Division, Berelson had done much to stimulate initial interests among social scientists in the border zone between economics and behavioral science. Economists who worked as behaviorists in that zone tended to agree that Zeuthen had in fact elucidated the essence of the bargaining process. Jan Pen insisted that "Hicks' reasoning is all about the limits of the contract zone and explains nothing of what happens between these limits." ${ }^{46}$ G.L.S. Shackle denied Hicks the right to assume that each party possessed complete knowledge of the other: "determinancy of the price is only secured at the sacrifice of the essence of bargaining, namely, the interplay of threat, bluff, and deception, the endeavor to trade upon the adversary's uncertainty." 47 The effectiveness of a threat was seen as a function of the adversary's estimate of the risk attached to ignoring it. Assumptions like that, plus a stress on the tactics involved in making rational choices, became the foundation tools of those theoreticians who, by incorporating statistical and mathematical techniques into economic thought, attempted to limit the scope of rationality in bargaining along a situational continuum that purported to be rational.

It is the special relationship between Boulding and Schelling in these years between 1957 and 1960, however, that reveals especially well the process that brought game theory out of RAND and toward students of labor relations. Each man was unusual. Boulding, by himself, had broken out of the confines of traditional scholarly disciplines, in part because of the Center of Conflict Resolution he helped to establish at Michigan, but also because of his own farranging interests. He examined subjects related to the bargaining theories of both industrial and international relations. $\mathrm{He}$ commented upon theories of bilateral mon-

\footnotetext{
${ }^{46} \mathrm{Jan}$ Pen, "A General Theory of Bargaining," American Economic Review, Vol. 42, No. 1 (March 1952), pp. 25-36.

${ }^{47}$ G.L.S. Shackle, "The Nature of the Bargaining Process," in John T. Dunlop, The Theory of Wage Determination (London: The Macmillan Co., 1957), p. 313.
} 
opoly, the limits of profit maximization, the strategic complexities of game theory, and the relationship among expectations and uncertainty and risk. As an outgrowth of "a passionate conviction" that "war was the major moral and intellectual problem of our age," he struggled with theories about war and peace in international relations; in his theoretical work, however, he included an essay on industrial conflict in order to develop his model of international conflict. He explained the exclusion of a more lengthy consideration of industrial relations by asserting that much of the groundwork had already been prepared:

Industrial conflict is . . . a curiously ambivalent affair, closer to the domestic battle of the sexes than to the clash of armies. Consequently, it is not difficult to build upon the positive sum or cooperative aspects of the game and to develop institutions that express this aspect. This perhaps is why the union, which may have been originally devised to prosecute conflict, may in cases become an instrument to resolve it in a way, for instance, that an army never does. ${ }^{48}$

It had seemed that Boulding in Michigan was alone in choosing to study industrial and international relations in a separate but related fashion; but, in fact, Schelling was cutting across his path. He submitted to Boulding an article on "Bargaining in the Absence of Communication Among Bargainers." 49 Boulding remembered that he accepted the piece with "great enthusiasm and encouraged him to go on with it"; under a different title he published the paper in 1957; a year later he published Schelling's "The Strategy of Conflict: Prospectus for a Reorientation of Game Theory," a paper Schelling had sent to the Michigan group from RAND, where he was then a fellow. ${ }^{50}$ Rapoport and Kelman shared this respect for Schelling in spite of the moral tension

\footnotetext{
${ }^{48}$ Kenneth E. Boulding, A Reconstruction of Economics (New York: Wiley, 1950), pp. 60, 67-71, 81-82, 99-101, 117-33, 225; Kenneth E. Boulding, Conflict and Defense: A General Theory (New York: Harper, 1962), p. viii (quotation from p. 226).

${ }^{49}$ Boulding to Korman.

${ }^{50}$ Thomas Schelling, "Bargaining, Communication and Limited War," Journal of Conflict Resolution, Vol. 1, No. 1 (March 1957), pp. 19-36 and "The Strategy of Conflict: . . . Game Theory," Journal of Conflict Resolution, Vol. 2, No. 3 (September 1958), pp. 203-64.
}

existing between the military orientation of RAND and the pacifist one at Michigan. ${ }^{51}$ In time, in fact, Schelling became especially important to students of labor relations.

\section{Schelling's Contribution}

A professor of economics and an associate at Harvard's University Center for International Affairs, Schelling put forward in 1960 a theory of bargaining with an integrative potential: The Strategy of Conflict. This was particularly remarkable because of the colleagues he encountered during his year at RAND Corporation: theorists who advocated mathematical formulae to explain the technical aspects of deterrence and reconnaissance. After all, the proliferation of game theorists was still one of RAND's specialties. Nevertheless, Schelling emerged with a strategy of conflict that contended that there were "enlightening similarities between, say, maneuvering in limited war and jockeying in a traffic jam, between deterring the Russians and deterring one's own children, or between the modern balance of terror and the ancient institution of hostages." ${ }^{52}$

Schelling transcended Boulding by incorporating similarities into his theoretical exposition that the latter merely drew upon by allusion. ${ }^{53}$ The subject matter of Schelling's book could be construed as game theory; but he concentrated upon situations in which there was a common interest as well as conflict between adversaries. It was precisely among these variations of the negotiating problem that game theory had, up to that point, made the least progress.

The distinction between explicit bargaining and tacit bargaining, in which knowledge of the adversary is reasonably complete, was one of the most important subtleties in Schelling's discussion. He explained that tacit bargaining most often required co-

\footnotetext{
${ }^{51}$ Boulding to Korman, August 27, 1975; interview with Kelman.

${ }^{52}$ Schelling, Strategy of Conflict (Cambridge: Harvard University Press, 1960), pp. v-vi. One of his colleagues at RAND recalled overhearing Schelling apply his strategy to his own children's conflicts (Interview with Myron Rush, May 1976).

${ }^{53}$ The discussion of Schelling is based on the Strategy of Conflict, pp. 9-10, 21-46, 54ff., 88-89, 128.
} 
ordination for a common gain while explicit bargaining did not. Tacit bargaining, therefore, was as applicable to companies and unions, which shared a long-term commitment to avoid conflict, as it was to nations and families, who shared a similar goal in maintaining peace.

Bargaining power was defined, paradoxically, not as a measure of superior strength, intelligence, or financial resources, but as the ability to incur a commitment to a given position and to communicate it persuasively to the other party. Institutional and structural characteristics of negotiations were brought to bear on the process. A bargaining agent might communicate commitment effectively since he was viewed as a party who was bound by predetermined instructions. Simultaneous negotiations would enable the party who successfully arranged such a calendar to argue that a concession in one contest would prejudice that party's bargaining reputation in other contests. The ability to communicate a convincing promise, as well as a convincing threat, was an important contribution to the party's bargaining success.

In discussing game theory, Schelling noted that its contribution to international strategy had "been extremely helpful in the formulation of problems and the clarification of concepts," but on the whole, it had "been pitched at a level of abstraction where it has made little contact with the elements of a problem like deterrence." Schelling argued that the "present deficiencies are not in the mathematics, and that the theory of strategy has suffered from too great a willingness of social scientists to treat the subject as though it were, or should be, solely a branch of mathematics."

In developing a reorientation of game theory, Schelling pointed out that the traditional references to basic concepts in the literature were formed without regard for the relationships among the players. Rejecting pure conflict as an abstraction of little use in the majority of genuine bargaining situations, Schelling preferred to deal in terms of games of coordination that reflected the sharing of interests and mixed-motive games in which coexisting elements of mutual dependence and conflict had to be resolved. Game theory had become endowed with pure conflict-oriented connotations, and he suggested that a "theory of interdependent decision" might be a more appropriately neutral term.

For students of labor relations another strength of the Schelling thesis rested in its ability to incorporate diverse stands from many of the otherwise isolated disciplines. The von Neumann-Morgenstern discussion had been conspicuously lax in its treatment of the wage determination controversies that had preceded it. Although Schelling devoted a great deal of attention to the problems of limited war, nuclear proliferation, and deterrence, he showed an equal familiarity with the problems of duopoly, bilateral monopoly, price war, and economic competition. In spite of his use of mathematics to illustrate strategic moves, Schelling did not consider it irrelevant to stress sociologist Erving Goffman's "nice everday" examples as illustrations of the relationship "of game theory to gamesmanship and ... the rich game-theoretic content of formalized behavior structures like etiquette, chivalry, diplomatic practice, andby implication-the law."

\section{Conclusion}

Events from the Manichean period had brought Schelling and Boulding across each other's paths to serve in special roles in applying game theory to the analysis of industrial conflict. Carl M. Stevens, who came out of psychological choice theory and studies with Dunlop, found Schelling "on bargaining theory and on reoriented game theory a source of stimulation." 54 There were others as well in industrial and labor relations who benefited from the Manichean period's special affinity to problems of international conflict. (In Bargaining: Formal Theories of Negotiations, Oran Young's bibliographical references to those years stand as a silent tribute. ${ }^{55}$ )

But the work of Walton and McKersie

${ }^{54}$ Carl M. Stevens, Strategy and Collective Bargaining Negotiation (New York: McGraw-Hill, 1963), p. xiii.

${ }^{55}$ Oran Young, Bargaining: Formal Theories of Negotiations (Urbana: University of Illinois Press, 1975), pp. 409-12. 
best illustrates the point, for their work was an excellent example of the sort of social scientific orientation the Gaither report had advocated. They rested their book on von Neumann and Morgenstern and on the sort of studies that the Ford Foundation had financed since the establishment of the RAND Corporation. They had three touchstones: "the field of study of collective bargaining; the emerging field of conflict resolution; and the underlying disciplines of economics, psychology, and sociology." They wrote for three different audiences. For students and teachers of industrial relations "we have attempted to close the gap between ... empirical case studies ... and the literature on bilateral monopoly, decision theory, experimental games, small group problem solving, attitude change, and role conflict." For social scientists "interested in the general field of conflict resolution we have attempted to show the fruitfulness of a more or less exhaustive treatment of a specific type of conflict-resolution process in one setting, ... negotiations and labor management." For practitioners of collective bargaining and other persons who are directly involved in international negotiations and civil rights negotiations, "we have attempted a comprehensive enumeration of tactical behaviors."

Finally, Walton and McKersie's $A B e$ havioral Theory of Labor Negotiations was also a work shaped by the Manichean character of those years. In 1964, when they offered their book as a contribution to science and society, they turned to Boulding and the other editors of the Journal of Conflict Resolution for their expression of faith:

. . . we welcome insights, theoretical models, and confirmatory tests from all spheres of conflict resolution; for we believe that only as all such areas are drawn on, can we devise an intellectual engine of sufficient power to move the greatest problem of our time-the prevention of war. ${ }^{56}$

After 1964, the republic's Manichean years gave way to a period more akin to that for which institutional economists had developed their approaches and methods. ${ }^{57}$

\footnotetext{
${ }^{56}$ Journal of Conflict Resolution, Vol. 1, No. 1 (March 1957), p. 2 quoted in Walton and McKersie, $A$ Behavioral Theory, pp. 2-3; see also pp. vii-viii, 6-10.

${ }^{57}$ The subsequent statements in this paragraph are
}

When Peking broke with Moscow the perceived bipolar politics of the 1940s and 1950s started to make way for a succession of multiple centers of power. The Gulf of Tonkin resolution served the Johnson administration as justification for sending drafted combat troops into battle zones of Vietnam's war, which neither Russia nor China seemed capable of controlling. For many Americans the war "for" South Vietnam, but against neither Moscow nor Peking, became an unpopular one. In the meanwhile the drive for equal opportunity at home had fashioned coalitions making forceful demands on government at all levels of the republic. As a result of these events at home and abroad, domestic conflicts became intense and violent. The mushrooming of public employment and ethnic and female power consciousness exacerbated some of these competitive struggles and sustained others after the shrillest voices had been stilled by Richard Nixon's resignation and the defeat in Vietnam. Conflicts of interest among competing groups of free citizens appeared as complex as they had been before "measuring social scientists" had come upon the scene. The problem of shaping public policy in response to those citizens and their interests also remained as difficult as ever.

It appears that game theory's wartime connections had facilitated its application to the study of labor relations during a unique period. Much more study of these years of hot and cold war is surely necessary in order to evaluate properly their significance in the history of industrial and labor relations. It is clear, however, that in the Manichean years fear of ideological or military defeat, or fear of war itself, had served as a powerful catalyst for finding ways to apply mathematical theory and statistics in order to make social science more systematic,

based on a context identified in the following: Zbigniew Brzezinski, "Threat and Opportunity in the Communist Schism," Foreign Affairs, Vol. 41, No. 3 (April 1963), pp. 513-25; William E. Leuchtenburg, "The Travail of Liberalism: American Society 1961 to the Present,"' in Leuchtenburg, et al., The Unfinished Century, pp. 803-938. Lloyd C. Gardner, Walter F. LaFeber, and Thomas J. McCormick, Creation of the American Empire (New York: Rand McNally, 1973), pp. 423-93. 
reliable, and predictable. Game theory offered one important contribution to that transformation, and in that context game theory was applied, tested, criticized, and made suitable for students of labor relations who also wanted to use statistics or mathematics in their field.

It is also clear that game theory, and the statistical thinking associated with it, became a permanent part of the study of labor relations during a period when, especially in mass-production industry, much of what peculiarly characterized contemporary industrial and labor relations entrenched itself in American society. Most arbitrators influential in labor relations since World War II had received their training with the War Labor Board or other hot and cold war agencies that had sought to stabilize industrial and labor relations. The grievance procedure, culminating in compulsory arbitration, was a wartime product in the sense that it received an extraordinary push from the federal government, eager to stabilize conflict, and from citizens who feared industrial unrest as a prelude to radicalism and Communism. Congress's Taft-Hartley and Landrum-Griffin Acts and the Supreme Court's Steelworkers' Trilogy decisions became the law of the land. ${ }^{58}$

Finally, it seems useful to point out that even though "measuring social scientists" have increased in importance in the study of

\footnotetext{
${ }^{58}$ The remarks about the grievance procedure and arbitration are based on a study Gerd Korman is preparing for publication.
}

industrial and labor relations since 1964, more of them now seem prepared to acknowledge unwarranted presumptuousness about the complex subjects they examine or seek to affect in shaping public policy. To be sure, assumptions about humanists and experimental physical scientists continue to shape the conviction that the quantifier is the most rigorous of investigators and therefore the most reliable of guides to knowledge and understanding. But, even as they criticized institutionalists for concentrating on descriptive detail and case studies, some quantifiers sounded a modest note: "Too often we have been content to derive our hypotheses and estimate our regressions in at least a partial vacuum of knowledge about the institutions with which we deal. . . ." 59 That particular admission came more than 30 years after The Theory of Games was first published. It may suggest, symbolically speaking, that von Neumann and Morgenstern's camel was finding trainers more respectful of traditional economics than in the past; after all, they had come face to face with complex conflict in a republic freed from the constraints of the Manichean period.

59 "Policy Decision and Research in Economics and Industrial Relations: An Exchange of Views," Industrial and Labor Relations Review, Vol. 31, No. 1 (October 1977), pp. 3-17, quotation from Ronald G. Ehrenberg, Daniel S. Hamermesh, and George E. Johnson, "Comment," page 12. See also "Social Science: The Public Disenchantment, A Symposium," American Scholar, Vol. 45, No. 3 (Summer 1976), pp. 335-39. 